\title{
First Record of a River Otter, Lontra canadensis, Captured on the Northeastern Coast of Alaska
}

\author{
SHAWN P. HASKELL ${ }^{1}$ \\ ${ }^{1}$ LGL Alaska Research Associates, Inc., 1101 E 76th Avenue, Suite B, Anchorage, Alaska 99518 USA; e-mail: shawn.haskell@ \\ ttu.edu
}

Haskell, Shawn P. 2006. First record of a River Otter, Lutra canadensis, captured on the northeastern coast of Alaska. Canadian Field-Naturalist 120(2): 235-236.

\begin{abstract}
A River Otter (Lontra canadensis) was captured on the Beaufort Sea coast of northeastern Alaska during a coastal fish study in late July 2001. The otter was dead upon retrieval and of adult size. River Otter distribution is not known to extend north of Alaska's Brooks Range. This occurrence may have represented a one-time spring dispersal event. However, fluviomorphological features of some river systems may provide suitable habitat for an overwintering otter in this region of Alaska's North Slope.
\end{abstract}

Key Words: River Otter, Beaufort Sea, Lutra canadensis, fyke net, distribution, Alaska.

In late July 2001, a River Otter (Lontra canadensis) of adult size was retrieved from a shoreline fyke net in Lions Bay, a barrier island lagoon system on the Beaufort Sea coast of northeastern Alaska. The live-capture fishing net was located at $70^{\circ} 10.024 \mathrm{~N}$, $146^{\circ} 12.557^{\prime} \mathrm{W}$, approximately $82 \mathrm{~km}$ east of Prudhoe Bay and $11 \mathrm{~km}$ west of the Canning River; the nearest non-industrial areas of human habitation are Barter Island, $100 \mathrm{~km}$ to the east, and the Colville River delta, $170 \mathrm{~km}$ to the west. A westerly wind event had caused coastal water levels to rise, completely submerging the trap-end of the net in about $1.5 \mathrm{~m}$ of water, drowning the otter. Physical samples or measures were not taken of the specimen. The animal was discarded to the water at the capture site. About two weeks after the capture, the author retrieved the carcass for brief examination. Marine arthropods of the family Mysidae had entered all openings in the otter's body, expediting decomposition.

River Otter distribution is commonly noted as extending far north up the Mackenzie River drainage of northwestern Canada but then falling south of the Alaskan Brooks Range to the west (Rue 1981; Whitaker 1996; Forsyth 1999; Wilson and Ruff 1999). Bee and Hall (1956) reported a River Otter sighting in the central Brooks Range at Kanayut Lake and tracks observed near the Beaufort Sea coast at the Kuparuk River. Manville and Young (1965) also displayed a point location near the mouth of the Kuparuk River, but given survey methods, that point may stem from the same observation of tracks documented by Bee and Hall (1956). A commercial winter fishery operated in the Colville River Delta since the early 1950s has never captured a River Otter (James Helmericks, homesteader and naturalist, personal communication). There are only two state sealing records for River Otters in Alaska's North Slope region; one was caught near Wainwright in northwestern Alaska in 1990 and the other near Anaktuvuk Pass in the central Brooks Range in 1985 (Geoff Carroll, Alaska Department of Fish and
Game Area Biologist, personal communication). Biologists have reported seeing small numbers (i.e., one or two) and tracks of otters north of Anaktuvuk Pass but south of the Arctic Coastal Plain on the Anaktuvuk and Chandler rivers, both tributaries to the north-flowing Colville River, where freshwater upwellings provide open water throughout winter and habitat for fishes such as Arctic char (Salvelinus alpinus; Geoff Carroll, Alaska Department of Fish and Game Area Biologist, personal communication).

It is unknown whether the 2001 otter capture in Lions Bay signified an anomalous extralimital occurrence or a case of regular periodic use by otters of this area seldom occupied by humans. Leffingwell (1919) noted that larger rivers in the region supported populations of fish year-round. Relatively small catches of juvenile amphidromous fishes during the summers of 1999 and 2001 in Lions Bay indicated that these fish, and likely some adults of the same species, did overwinter in the area (Griffiths et al. 2002*). Craig and McCart (1974*) identified groundwater springs in the nearby Kavik River and Canning River drainage, as well as a field of aufeis in the Canning River Delta, that supported overwintering fish. Some of these areas could potentially provide suitable habitat for an overwintering otter on Alaska's North Slope.

\section{Acknowledgments}

This capture occurred during the daily operation of a remote coastal fish study operated by LGL Alaska Research Associates, Inc. The study was funded by the Exxon Owners Group of Point Thomson, administered and reviewed by the Environmental Studies Group of BP Exploration (Alaska) Inc.

\section{Documents Cited (marked ${ }^{*}$ in text)}

Craig, P. C., and P. McCart. 1974. Fall spawning and overwintering areas of fish populations along routes of the proposed pipeline between Prudhoe Bay and the Mackenzie Delta. Chapter 3 in Fisheries research associated with proposed gas pipeline routes in Alaska, Yukon, and Northwest 
Territories. Edited by P. J. McCart. Arctic Gas Biological Report Series 15(3). 36 pages.

Griffiths, W. B., L. R. Martin, S. P. Haskell, W. J. Wilson, and R. G. Fechhelm. 2002. Nearshore Beaufort Sea fish studies in the Point Thomson area, 2001. Report for BP Exploration (Alaska) Inc. by LGL Alaska Research Associates, Inc., Anchorage, Alaska. 55 pages + appendices.

\section{Literature Cited}

Bee, J. W., and E. R. Hall. 1956. Mammals of northern Alas$\mathrm{ka}$ on the Arctic Slope. University of Kansas, Lawrence, Kansas.

Forsyth, A. 1999. Mammals of North America: temperate and arctic regions. Firefly Books Ltd., Willowdale, Ontario.

Leffingwell, E. K. 1919. The Canning River region, northern Alaska. Government Printing Office, Washington D.C.
Manville, R. H., and S. P. Young. 1965. Distribution of Alaskan mammals. Bureau of Sport Fisheries and Wildlife. Circular 211. U.S. Government Printing Office, Washington, D.C.

Rue, L. L., III. 1981 . Furbearing animals of North America. Crown Publishers, Inc., New York.

Whitaker, J. O., Jr. 1996. National Audobon Society field guide to North American mammals. Alfred A. Knopf, Inc., New York.

Wilson, D. E., and S. Ruff. 1999. The Smithsonian book of North American mammals. UBC Press, Vancouver/Toronto.

Received 4 August 2002

Accepted 24 December 2004 